\title{
Origin, migration, and accumulation of carbon dioxide in the East Changde Gas Field, Songliao Basin, northeastern China
}

\author{
Yu-Ming Liu ${ }^{1} \cdot$ Yue Dong ${ }^{2,3} \cdot$ Zhen-Hua Rui $^{4} \cdot$ Xue-Song $\mathrm{Lu}^{3} \cdot$ Xin-Mao Zhou ${ }^{3} \cdot$ Li-Chun Wei $^{1}$
}

Received: 21 August 2017 / Published online: 16 October 2018

(C) The Author(s) 2018

\begin{abstract}
$\mathrm{CO}_{2}$ reservoirs are widely distributed within the Yingcheng Formation in the Songliao Basin, but the extreme horizontal heterogeneity of $\mathrm{CO}_{2}$ content causes difficulties in the exploration and exploitation of methane. Former studies have fully covered the lithology, structure, and distribution of the reservoirs high in $\mathrm{CO}_{2}$ content, but few are reported about migration and accumulation of $\mathrm{CO}_{2}$. Using the East Changde Gas Field as an example, we studied the accumulation mechanisms of $\mathrm{CO}_{2}$ gas. Two original types of accumulation model are proposed in this study. The fault-controlled accumulation model refers to gas accumulation in the reservoir body that is cut by a basement fault (the West Xu Fault), allowing the hydrocarbon gas generated in the lower formation to migrate into the reservoir body through the fault, which results in a relatively lower $\mathrm{CO}_{2}$ content. The volcanic conduit-controlled accumulation model refers to a reservoir body that is not cut by the basement fault, which prevents the hydrocarbon gas from being mixed in and leads to higher $\mathrm{CO}_{2}$ contents. This conclusion provides useful theories for prediction of $\mathrm{CO}_{2}$ distribution in similar basins and reservoirs.
\end{abstract}

Keywords Carbon dioxide reservoir $\cdot$ Mantle-derived $\mathrm{CO}_{2} \cdot$ Faults $\cdot$ Reservoir formation mechanism $\cdot$ East Changde Gas Field · Songliao Basin

\section{Introduction}

The Songliao Basin is a Mesozoic-Cenozoic basin located in northeastern China that contains abundant oil and gas resources. Several billion tonnes of oil have been discovered in the basin's oil fields since exploration began in 1950. However, in addition to the large amount of hydrocarbon gas, a number of $\mathrm{CO}_{2}$ reservoirs, whose $\mathrm{CO}_{2}$ concentrations vary significantly from $<30$ to $>98 \%$, have

Edited by Jie Hao

Yu-Ming Liu

liuym@cup.edu.cn

$\triangle$ Zhen-Hua Rui

zhenhuarui@126.com

1 College of Geosciences, China University of Petroleum, Beijing 102249, China

2 School of Energy Resources, China University of Geosciences, Beijing 100083, China

3 Research Institute of Petroleum Exploration and Development, CNPC, Beijing 100083, China

4 Independent Project Association, Inc., Leesburg, USA also been accidentally discovered during natural gas exploration over the past two decades (Xu et al. 1995; Sun et al. 2009; Guo et al. 2017a, b). These $\mathrm{CO}_{2}$ reservoirs are located within a narrow strip within the Xujiaweizi Depression, the Changling Depression, and the Wanjinta Depression. However, $\mathrm{CO}_{2}$ accumulation has an extremely heterogeneous horizontal distribution. The difference in the $\mathrm{CO}_{2}$ content of two wells located less than $1 \mathrm{~km}$ apart can be as much as $70 \%$. For example, the Changde area in the Xujiaweizi Depression has a complex gas genesis, with both organic gas (methane) and inorganic gas $\left(\mathrm{CO}_{2}\right)$. Reservoirs with $\mathrm{CO}_{2}$ contents $>84 \%$ have been discovered in the volcanic reservoirs, e.g., in wells Fs9 and Fs701 in the Yingcheng Formation in East Changde. Whereas, in wells Fs7 and Fs6, located less than $3 \mathrm{~km}$ away, the $\mathrm{CO}_{2}$ content is $15 \%-40 \%$. This phenomenon has resulted in a great deal of interest in the genesis of $\mathrm{CO}_{2}$ and the reservoir formation process in the Songliao Basin (Yang et al. 2011; Fu and Song 2005; Shao et al. 2000; Qu et al. 2016; Xu et al. 1999; Dai 1996; Du 2005; Guan 1990; Zhang et al. 2009; Li et al. 2006; Guo et al. 2000; Yu et al. 2010; Cao 1996; Rui et al. 2018a, b). Most scholars agree that the $\mathrm{CO}_{2}$ in the Songliao Basin is inorganic and mantle-derived 
according to the isotopic composition of the $\mathrm{CO}_{2}$. It is generally accepted that mantle fluids, especially basaltic magmas, contain significant amounts of volatiles, such as $\mathrm{CO}_{2}, \mathrm{H}_{2} \mathrm{O}$, and $\mathrm{He}$. When the temperature decreases as upwelling occurs, the magma will degas, and these volatiles will continuously migrate through fractures and pores, and can be trapped in $\mathrm{CO}_{2}$ reservoirs under the appropriate conditions. This is how mantle-derived $\mathrm{CO}_{2}$ reservoirs form (Yang et al. 2011). However, previous studies have failed to produce a reasonable explanation for the differences in the $\mathrm{CO}_{2}$ contents of reservoirs that are located fairly close together. Several scholars have proposed a selfgenerating and self-preserving reservoir formation model. They argue that the $\mathrm{CO}_{2}$ in the Songliao Basin is derived from magmas associated with Cretaceous volcanic activity. The $\mathrm{CO}_{2}$ degassed from these magmas due to decreasing temperatures when the magma cooled, and it was stored in situ forming reservoirs (Liu et al. 2005; Tan et al. 2005). According to this theory, there should be widespread $\mathrm{CO}_{2}$ reservoirs in the Songliao Basin wherever Cretaceous volcanic rocks are located. However, the $\mathrm{CO}_{2}$-containing reservoirs have a limited distribution-they are mainly located where faults intersect (Guo et al. 2000; Yu et al. 2010; Zeng et al. 2017). Due to the fact that the density of $\mathrm{CO}_{2}$ is greater than that of hydrocarbon gases, several scholars proposed the "gravitational differentiation" reservoir formation model, which concludes that gravity caused $\mathrm{CO}_{2}$ to accumulate at the bottom of reservoirs and hydrocarbon gases at the top (Lin et al. 2010; Wei et al. 2009). However, there is little difference between the density of $\mathrm{CO}_{2}$ and the densities of methane and ethane. Therefore, whether such a small density difference can lead to such a significant difference in the horizontal distribution of $\mathrm{CO}_{2}$ needs to be investigated further.

In this study, several typical reservoirs in East Changde were selected to investigate the genesis of $\mathrm{CO}_{2}$ using core data gas samples, temperature, pressure, and seismic data. Based on this data, the distribution characteristics of volcanic reservoirs and basement faults are discussed, and a $\mathrm{CO}_{2}$ migration and reservoir formation model for East Changde is explored in order to analyze the factors governing $\mathrm{CO}_{2}$ distribution in the Songliao Basin.

\section{Geological setting}

The Songliao Basin is the largest Mesozoic-Cenozoic continental basin in northeastern China. It is $750 \mathrm{~km}$ long, $330-370 \mathrm{~km}$ wide, and covers an area of nearly $255,000 \mathrm{~km}^{2}$, extending from north to south through Heilongjiang Province, Jilin Province, and Liaoning Province (Fig. 1). The Songliao Basin has experienced three phases of evolution, i.e., rift, depression, and structural inversion.
It has undergone widespread deposition of CretaceousQuaternary strata with a structure characterized by faults at the bottom and depressions at the top. Three structural layers can be identified: a fault-depressed structural layer, a depressed structural layer, and an inverted structural layer. During the past decade, several $\mathrm{CO}_{2}$ reservoirs or $\mathrm{CO}_{2-}$ containing reservoirs (fields) have been accidentally discovered during natural gas exploration in the Songliao Basin. Currently, there are multiple high $\mathrm{CO}_{2}$-content reservoirs and gas seepages, such as the $\mathrm{CO}_{2}$ gas seepages in the Five Connected Ponds on the north edge of the basin and the high $\mathrm{CO}_{2}$-content middle-shallow sand-conglomerate reservoirs located in the Wanjinta, Gudian, Qian'an, and Honggang Depressions. A number of $\mathrm{CO}_{2}$ reservoirs and gas spots in the volcanic reservoirs of the Yingcheng Formation were also recently discovered by deep exploration, such as the Fangshen $9\left(\mathrm{CO}_{2}\right.$ content $=84.2 \%$ $90.4 \%)$, Xushen $\left(\mathrm{CO}_{2}\right.$ content $\left.=24 \%\right)$, Xushen $10\left(\mathrm{CO}_{2}\right.$ content $=90 \%)$, Xushen $19\left(\mathrm{CO}_{2}\right.$ content $\left.=93 \%\right)$, Xushen $28\left(\mathrm{CO}_{2}\right.$ content $\left.=80.7 \%\right)$, and Dashen $2\left(\mathrm{CO}_{2}\right.$ content $=32 \%$ ) in the Xujiaweizi Depression, East Changde, in the northern part of the Songliao Basin (Lu et al. 2005, 2008; He et al. 2005) (Fig. 1). Thus, it can be concluded that $\mathrm{CO}_{2}$ is widely, but unevenly, distributed in the Songliao Basin. The absence of well-established conditions for industrial utilization and treatment of this $\mathrm{CO}_{2}$ has made it riskier and more difficult to explore and exploit the associated hydrocarbon gases.

\subsection{Structural characteristics}

Tectonically, the Changde area is located in the western slope in the Xujiaweizi Depression (Fig. 1). From a regional perspective, the western region is undergoing basement uplift and is split into a northern half and a southern half by the ancient valley running along Chang wells 101-102. Situated in the depression in the eastern part of the basement uplift, the East Changde Gas Field is a syncline structure trending northwest with a depth of up to $4100 \mathrm{~m}$. This syncline is characterized by simple structural features and some topographic highs. The sedimentary strata pinch out to the west above the basement uplift. The East Changde Gas Field is located in the western part of the Xujiaweizi Depression (Figs. 1, 2) where reservoirs are developed in the volcanic reservoir bodies in the Lower Cretaceous Yingcheng Formation.

There is a $2-6 \mathrm{~km}$, NNE-trending fault with a fault displacement of 40-100 m located in the syncline area of the northern part of the East Changde Gas Field. This is a long-lived normal fault that separates the Qingshankou Formation hanging wall and the Shahezi Formation foot wall. A 1-2-km-long, NS-trending fault is located to the 


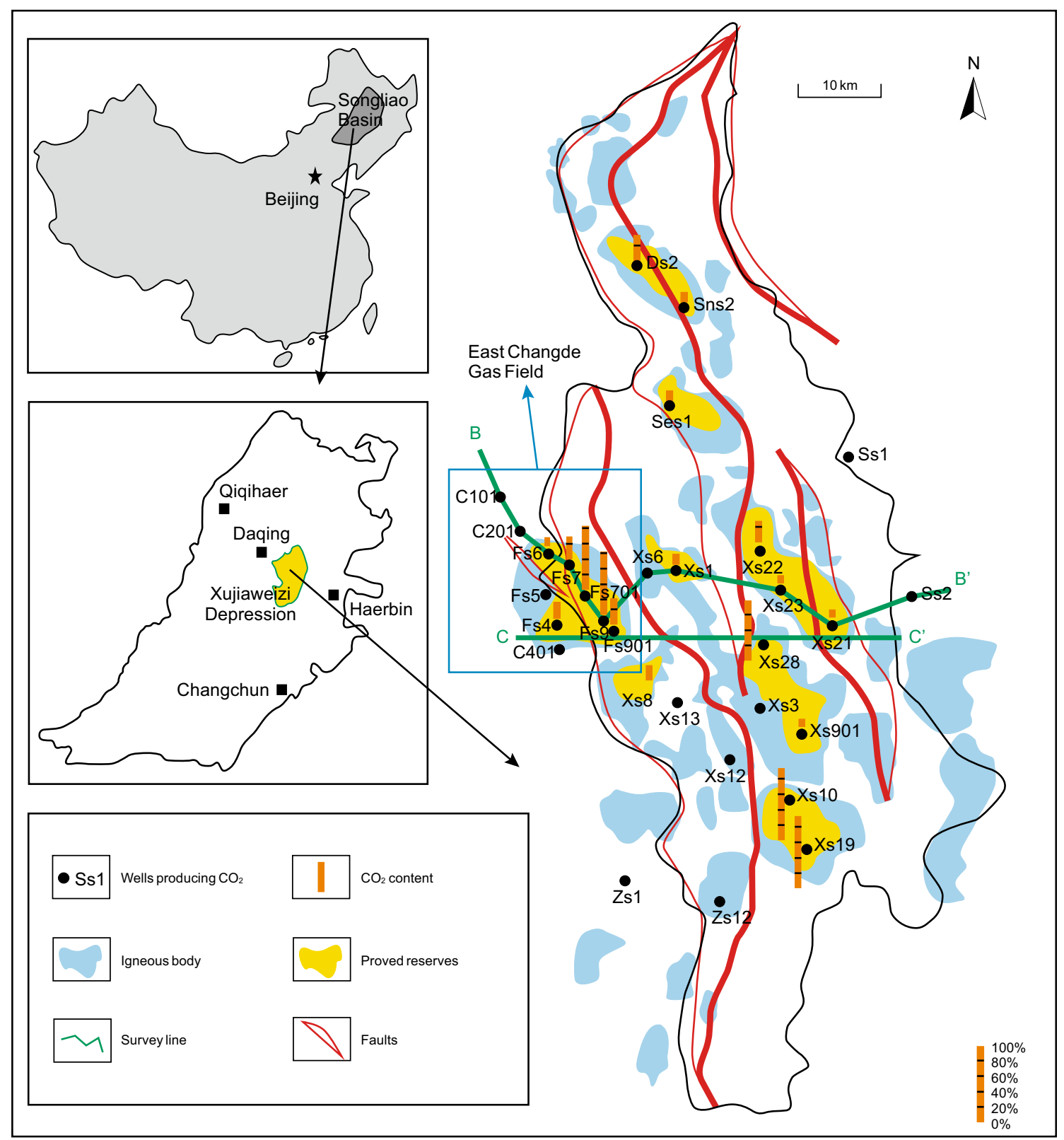

Fig. 1 Location of the Songliao Basin and the Xujiaweizi Depression. Modified from Lu Xuesong (Lu et al. 2009)

south where two primary fault characteristics are observed, i.e., the fault trends are close to that of a depression-controlling fault and the faults are located near a depressioncontrolling fault. These faults provide channels for gas migration and accumulation, control fracture development of reservoirs, and improve reserve and percolation capabilities of the reservoirs.

\subsection{Formation}

Gas reservoirs in East Changde are mostly located in the Lower Cretaceous volcanic strata, which is why this study focuses on the Lower Cretaceous strata (Fig. 3). Due to the fact that this area is an uplift structure developed on uplifted basement on the edge of a rift basin, part of the strata in the uplifted area is missing. The uplifted basement is mainly composed of metamorphic rocks and intrusive rocks, e.g., high-resistance phyllite and granite. From bottom to top, the Lower Cretaceous strata consist of the Huoshiling Formation, the Shahezi Formation, the Yingcheng Formation, the Dengloudu Formation, and the Quantou Formation. The Huoshiling Formation is composed of volcanic rocks and siltstone that unconformably overlie the basement and exhibit limited structural development. The locally well-developed Shahezi Formation is mainly composed of low-resistance dark mudstone, 


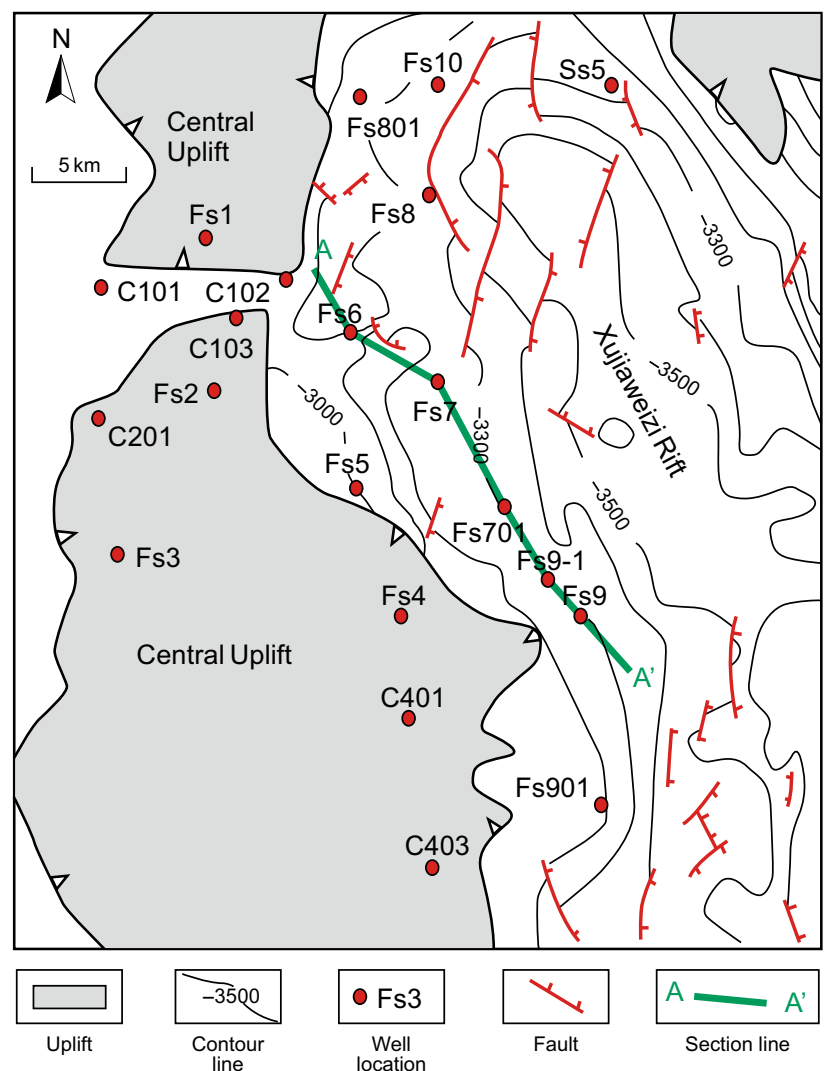

Fig. 2 Structure map of the Yingcheng Formation, East Changde Gas field

argillaceous sandstone, and sandy conglomerate. The Yingcheng Formation is divided into four members from bottom to top. The first member of the Yingcheng Formation, which contains volcanic rock reservoirs, is mainly composed of argillaceous siltstone, mottled sandy conglomerate, and volcanic rocks. The second and third members of the Yingcheng Formation are absent in this region. The compact volcanoclastic rocks of the fourth member of the Yingcheng Formation serve as the cap rocks for this region. The 20-65-m-thick first member of the Denglouku Formation is mainly composed of a set of mottled high-resistance conglomerate and sandy conglomerate stratum with a small amount of coarse sandstone and fine sandstone, which locally unconformably overlies the basement. The $80-120-\mathrm{m}$-thick second member of the Denglouku Formation is mainly composed of low-resistance dark mudstone, which serves as an effective regional cap rock. The 300-500-m-thick first and second members of the Quantou Formation are composed of coastal, shallow-lake, and fluvial mudstone with argillaceous sandstone and sandstone. These members also serve as regional cap rocks.

\section{Methods}

\subsection{Analytical methods}

A considerable amount of information was used in this study, including core samples, gas samples, and temperature and pressure data. The core samples were used to analyze the petrologic features of the volcanic reservoirs, and together with isotopic analyses of the gas samples, to determine the source of the $\mathrm{CO}_{2}$. Samples collected from different wells were analyzed to determine the characteristics of the volcanic reservoirs and their relationship to the nearby faults by analyzing the data in the context of the seismic, temperature, and pressure data. Based on these analyses, two models for $\mathrm{CO}_{2}$ migration and accumulation are proposed to further describe the factors governing $\mathrm{CO}_{2}$ reservoir distribution in the East Changde Gas Field, and possibly throughout the Songliao Basin.

\subsection{Data}

The data used for this study includes core samples, gas samples, seismic data, and temperature and pressure data for the reservoirs. See Table 1 for a summary of the data.

1. A total length of $205.9 \mathrm{~m}$ of core samples was collected from five wells, and the core samples were all from the first member of the Lower Cretaceous Yingcheng Formation.

2. Eleven gas samples were collected from five wells. Ten liters of gas was sampled from each well and stored in a cylinder under pressure. As shown in Table 1, the depth of each sample is the average depth of the perforation interval.

3. The seismic data, with a dominant frequency of $30 \mathrm{~Hz}$, covered $553 \mathrm{~km}^{2}$ of the Xujiaweizi area. A pre-stacked GR inversion was conducted on the volcanic reservoirs in the Yingcheng Formation, East Changde. Due to their high gamma ray value, which differs significantly from that of the surrounding rocks, we were able to precisely determine the distribution of the volcanic reservoirs in the section.

4. Temperature and pressure data was collected from the logging-while-drilling reports compiled by the China National Petroleum Corporation (CNPC) (Table 1 and Fig. 4).

\subsection{Geochemical analyses}

All of the experiments in this study were conducted at the Petroleum Geology Experiment Research Center, Research 


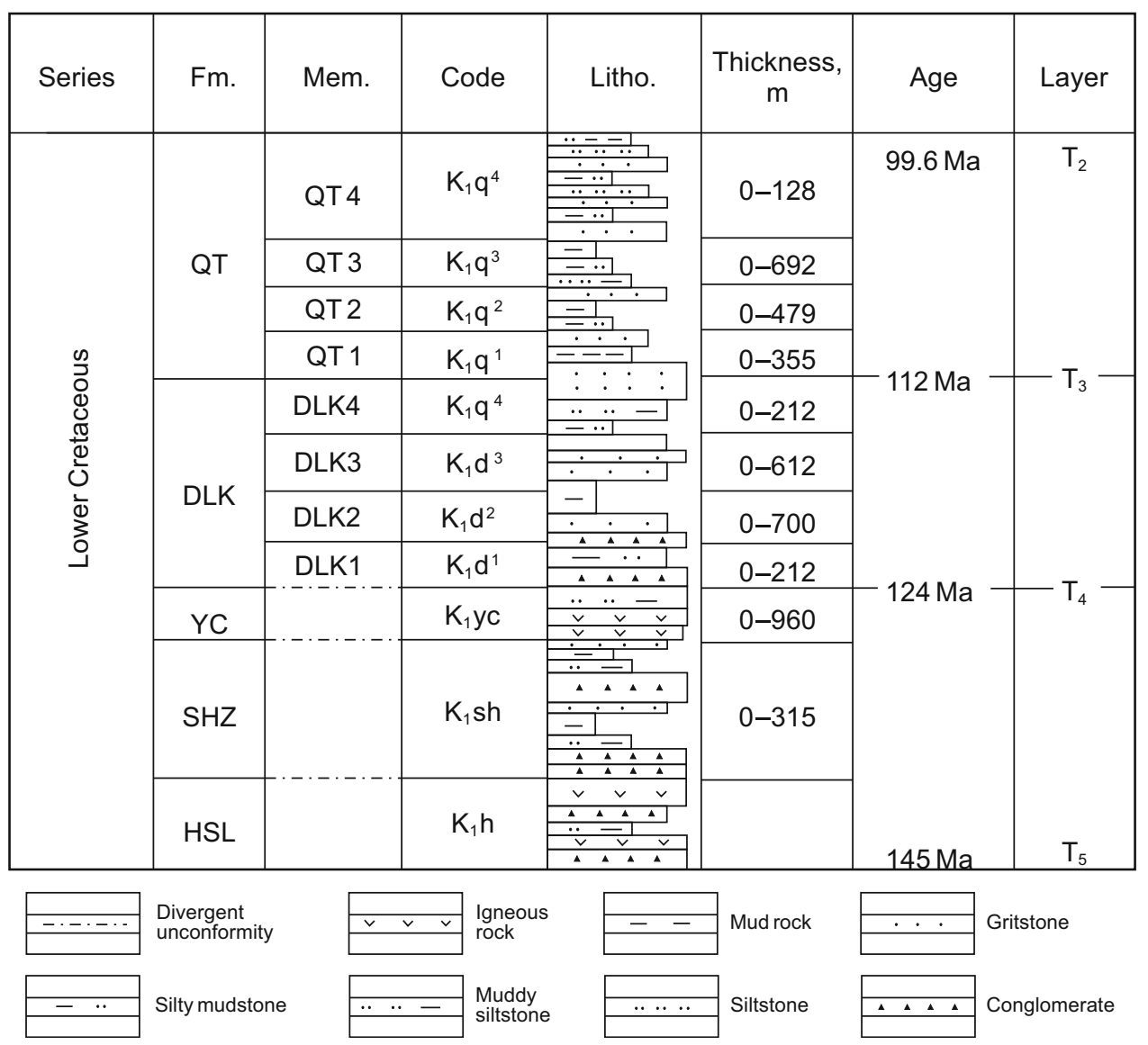

Fig. 3 Lower Cretaceous strata in East Changde

Table 1 Summary of data for the gas reservoirs in East Changde

\begin{tabular}{lllll}
\hline Well & Core depth, $\mathrm{m}$ & Gas sample depth, $\mathrm{m}$ & Temperature, ${ }^{\circ} \mathrm{C}$ & Pressure, MPa \\
\hline Fs6 & $3324.5-3379.3$ & 3250 & 137.2 & 33.5 \\
& & 3410 & 138.1 & 35.1 \\
Fs7 & $3473.6-3529.5$ & 3374 & 138.2 & 34.3 \\
& & 3490 & 139.5 & 35.2 \\
Fs701 & $3598.7-3623.2$ & 3580 & 138.1 & 34.1 \\
& & 3620 & 140.0 & 38.0 \\
Fs9 & $3646.8-3671.4$ & 3625 & 141.7 & 37.1 \\
& & 3640 & 142.0 & 38.1 \\
& & 3660 & 143.1 & 39.1 \\
Fs9-1 & $3560.1-3606.2$ & 3600 & 139.1 & 36.0 \\
& & 3650 & 142.5 & 38.9 \\
\hline
\end{tabular}

Institute of Petroleum Exploration and Development, Beijing, China.

1. Whole rock geochemical analyses were conducted on 52 samples from the 5 wells listed in Table 1. Sample preparation involved fusing $0.5 \mathrm{~g}$ samples of rock powder with $2.0 \mathrm{~g}$ of $\mathrm{LiBO}_{2}$ followed by dissolution in $200 \mathrm{~mL}$ of $5 \% \mathrm{HNO}_{3}$. Major oxide compositions were determined using inductively coupled plasma emission spectroscopy (ICP-ES). The results are shown in Fig. 5.

2. The gas samples were fed into a Thermo Fisher mass spectrometer through the output valve on the pressureretaining cylinder. He gas was absorbed by an active charcoal trap at $800{ }^{\circ} \mathrm{C}$, and the $\mathrm{CO}_{2}$ gas was cryogenically extracted using liquid nitrogen (Cao 1996). Then, the volume of $\mathrm{He}$ and $\mathrm{CO}_{2}$ was measured 


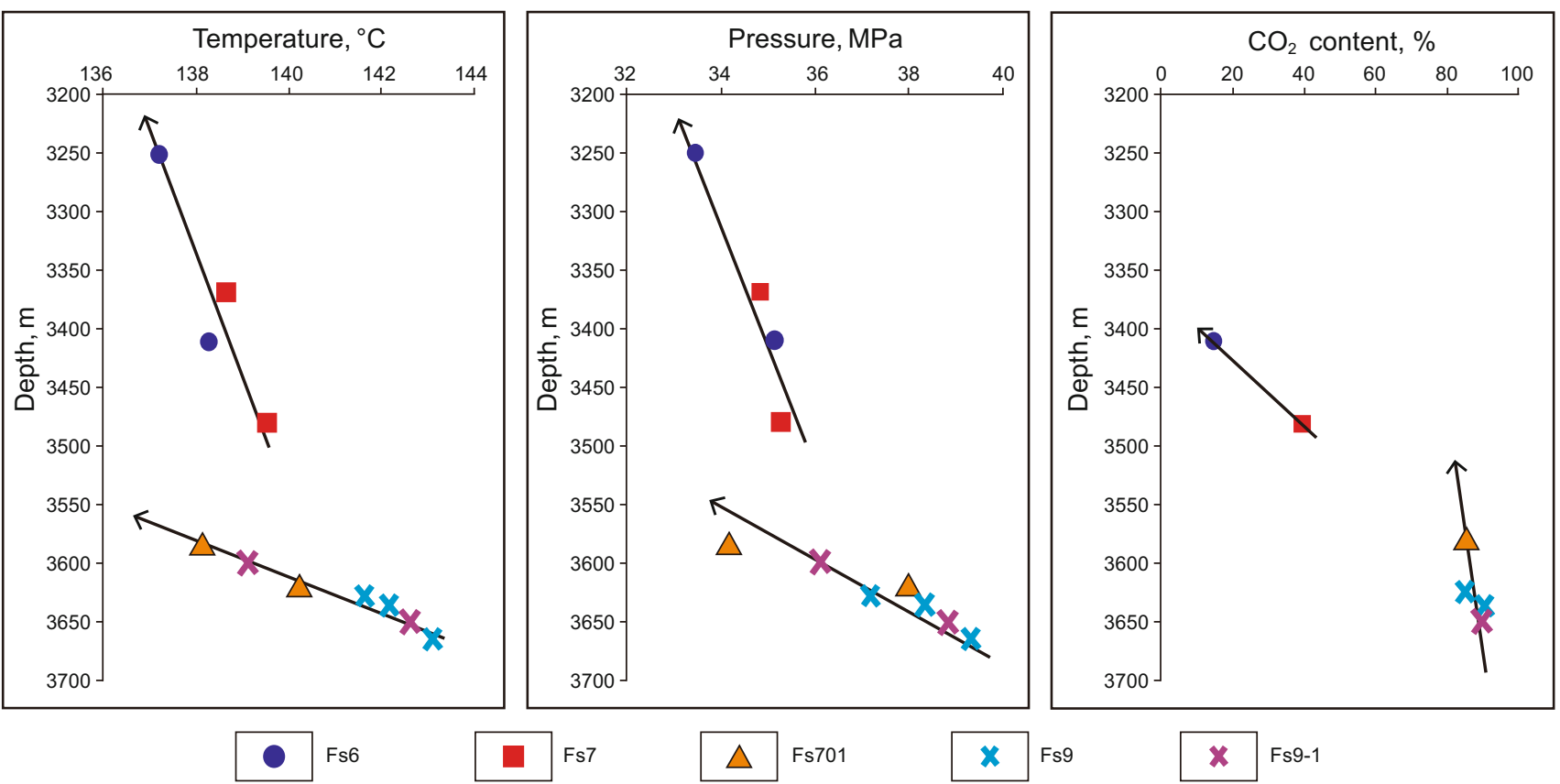

Fig. 4 Variations in reservoir temperature, pressure, and $\mathrm{CO}_{2}$ content with depth in East Changde

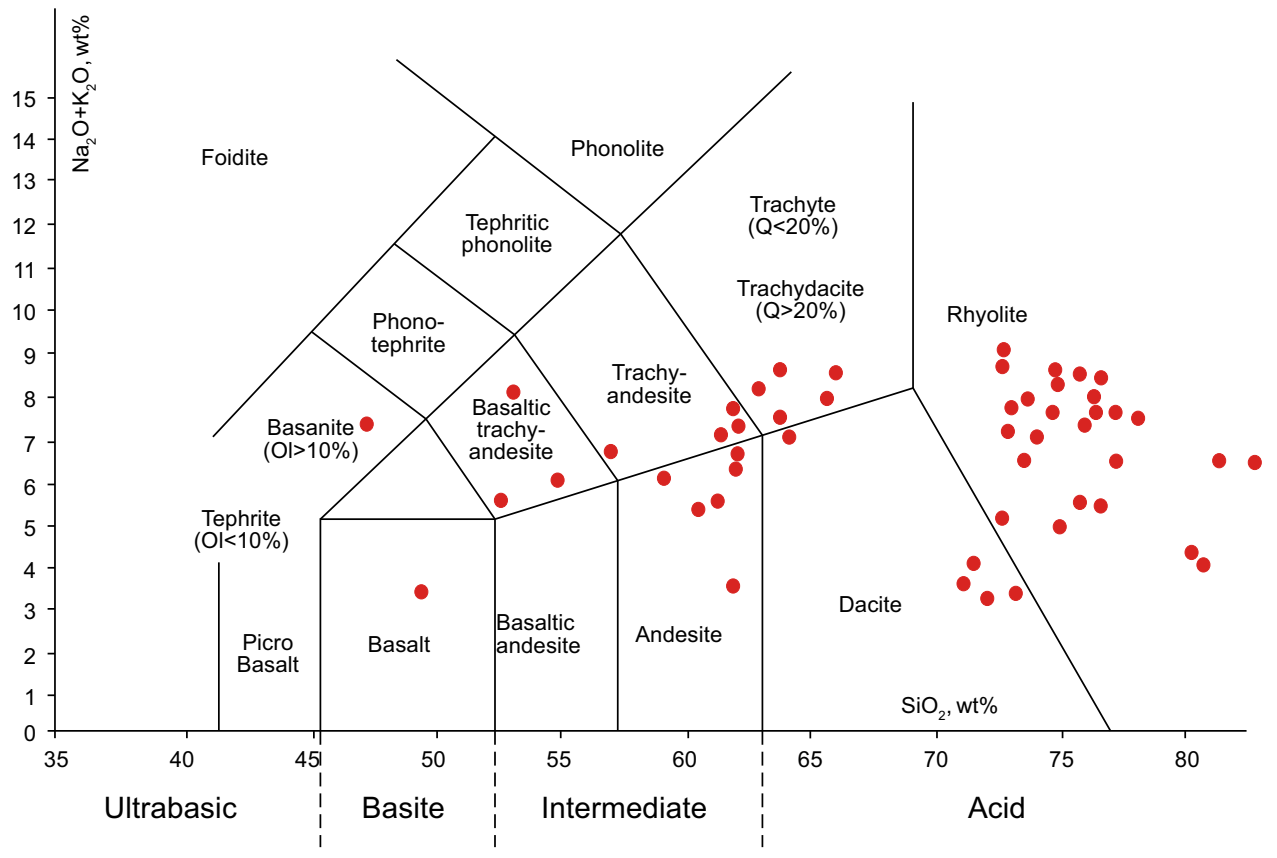

Fig. 5 Total alkali silica (TAS) diagram of the volcanic rocks of the Yingcheng Formation, Songliao Basin

at room temperature $\left(20{ }^{\circ} \mathrm{C}\right)$ and pressure. The results are shown in Fig. 6.

3. The $\mathrm{CO}_{2}$ and $\mathrm{He}$ were transferred to an airtight $2 \mathrm{~L}$ amber glass bottle. Two to three drops of $\mathrm{HgCl}_{2}$ solution $\left(3.7 \mathrm{~g} \cdot 50 \mathrm{~mL}^{-1}\right)$ were added to the glass bottle in advance to avoid a photochemical reaction. To prevent $\mathrm{CO}_{2}$ loss, $5 \mathrm{~mL}$ of $\mathrm{NaOH}$ solution was injected into the bottle through the cork to balance the
pH (Liu et al. 2005; Tan et al. 2005). $\delta^{13} \mathrm{C}$ and ${ }^{3} \mathrm{He}$ isotopic analyses of the $\mathrm{CO}_{2}$ and $\mathrm{He}$ were conducted using a Thermo Fisher mass spectrometer and the following formula:

$$
\delta^{13} \mathrm{C}=\left[\frac{\left({ }^{13} \mathrm{C} /{ }^{12} \mathrm{C}\right)_{\text {sample }}}{\left({ }^{13} \mathrm{C} /{ }^{12} \mathrm{C}\right)_{\text {standard }}}-1\right] \times 1000
$$




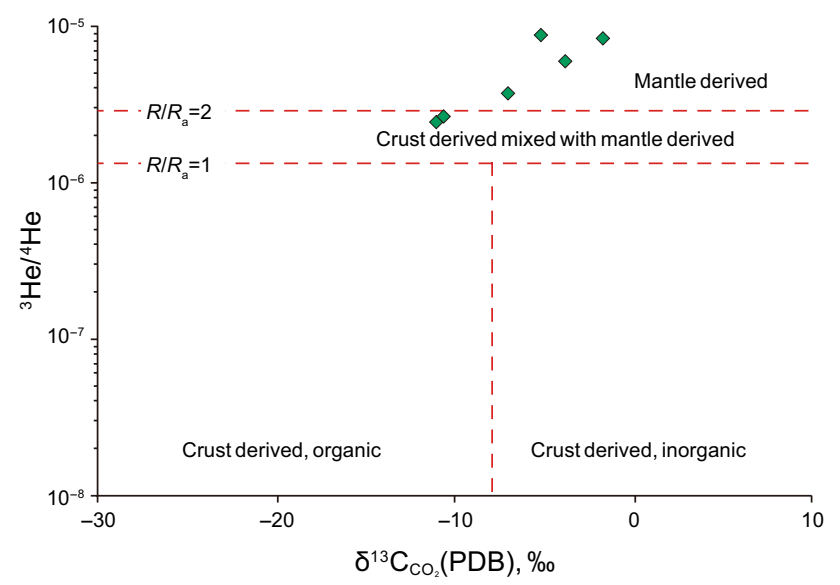

Fig. 6 Diagram of origin of $\mathrm{CO}_{2}$. Modified from He et al. (2005)

Each measurement comprised of three pulses of references followed by six pulses of sample $\mathrm{CO}_{2}$ or He gas. The parameters used are as follows. The chromatographic column was $30 \mathrm{~mm} \times 0.25 \mathrm{~mm}$; the column temperature was $300{ }^{\circ} \mathrm{C}$; the injection volume was $1 \mu \mathrm{L}$; the carrier gas was Ar; the gas flow was $1 \mathrm{~mL} / \mathrm{min}$; the split was 10:1; and the mass spectrometry conditions were an EI ion source of $70 \mathrm{eV}$, a nucleo-cytoplasmic ratio scan range of $\mathrm{m} / \mathrm{z}=80-700$. The precision for both $\delta^{13} \mathrm{C}$ and ${ }^{3} \mathrm{He}$ is \pm $0.1 \%$. The results are shown in Table 2 .

\section{Results and discussion}

\subsection{The origin of $\mathrm{CO}_{2}$ gas}

${ }^{13} \mathrm{C}_{\mathrm{CO}_{2}}, R / R_{\mathrm{a}}\left(R\right.$ is the ${ }^{3} \mathrm{He} /{ }^{4} \mathrm{He}$ value of the sample; $R_{\mathrm{a}}$ is ${ }^{3} \mathrm{He} /{ }^{4} \mathrm{He}$ value of air), and $\mathrm{CO}_{2} /{ }^{3} \mathrm{He}$ are the commonly used indices for source determination of $\mathrm{CO}_{2}$. The first of which is used to determine whether the gas has an organic or inorganic genesis, while the latter three are used to determine whether the gas is crust- or mantle-derived (Ballentine et al. 2000; Marty et al. 1989; Trull et al. 1993). It is generally agreed that a ${ }^{13} \mathrm{C}_{\mathrm{CO}_{2}}$ of $>-10 \%$ indicates an inorganic origin, and $R / R_{\mathrm{a}}>2$ and $\mathrm{CO}_{2} /^{3} \mathrm{He}>2 \times 10^{9}$ indicate a mantle origin (He et al. 2005). Table 2 shows the helium isotope and $\mathrm{CO}_{2}$ isotopic data for the East Changde samples. Besides, it is important to make clear whether $\mathrm{He}$ and $\mathrm{CO}_{2}$ are coupled, otherwise $R / R_{\mathrm{a}}$ would be meaningless. Lu XS (Liu et al. 2016) has done detailed research about $\mathrm{CO}_{2}$ and $\mathrm{He}$ gas in Songliao Basin and concluded that they are from the same origin.

As shown in Table 2, the ${ }^{13} \mathrm{C}_{\mathrm{CO}_{2}}$ values for Well Fs7 are $-10.07 \%$ and $-11.51 \%$, which are slightly less than $-10 \%$, indicating a combined organic-inorganic genesis, with the inorganic genesis of $\mathrm{CO}_{2}$ being dominant. The ${ }^{13} \mathrm{C}_{\mathrm{CO}_{2}}$ from the other four wells were greater than $-8 \%$, indicating an inorganic genesis. As a result, it is concluded that the $\mathrm{CO}_{2}$ in East Changde has a broad inorganic origin. Helium isotope ratios suggest that the $R / R_{\mathrm{a}}$ value in East Changde is between 2.35 and 3.68 (except for that of Well Fs7), which is much higher than the criterion for mantlederived genesis, i.e., $R / R_{\mathrm{a}}>2$ (Fig. 6). In addition, the $\mathrm{CO}_{2} /{ }^{3} \mathrm{He}$ ratio of the gas from Well $\mathrm{Fs} 9$ is $(1.96-1.97) \times 10^{9}$ (close to $\left.2 \times 10^{9}\right)$, which is close to the $\mathrm{CO}_{2} /{ }^{\beta} \mathrm{He}$ ratio of primitive magma generated in the upper mantle (Sano et al. 1986). Based on this evidence, we conclude that the $\mathrm{CO}_{2}$ in East Changde is mantle-derived.

Geochemical analysis of the volcanic rocks provided a basis for the further determination of the origin of the $\mathrm{CO}_{2}$. According to the TAS diagram (Fig. 5) of the Yingcheng Formation (Mesozoic) volcanic rocks from the Songliao Basin, the Mesozoic volcanic rocks are mainly silicic and intermediate rocks (rhyolites, dacites, and andesites) and a small amount of mafic rocks formed by crust-derived magma. Detailed studies have shown that silicic and intermediate magmas could not preserve large amount of volatile gases, since these magmas lack large ion lithophile elements (LILEs) and light rare earth elements (LREEs) which are $\mathrm{CO}_{2}$ loving (Mysen et al. 1975); while in East Changde reservoirs, $\mathrm{CO}_{2}$ content is up to $87.2 \%$. This contradiction shows that high $\mathrm{CO}_{2}$-content reservoirs are

Table 2 Carbon and helium isotopic data for the $\mathrm{CO}_{2}$ reservoirs in East Changde

\begin{tabular}{|c|c|c|c|c|c|c|c|c|c|}
\hline \multirow[t]{2}{*}{ Well no. } & \multirow[t]{2}{*}{ Fm. } & \multirow[t]{2}{*}{ Well depth, $\mathrm{m}$} & \multicolumn{4}{|c|}{ Content of natural gas component, $\%$} & \multirow[t]{2}{*}{${ }^{13} \mathrm{C}_{\mathrm{CO}_{2}}, \%$} & \multirow[t]{2}{*}{$R / R_{\mathrm{a}}$} & \multirow[t]{2}{*}{$\mathrm{CO}_{2} /{ }^{3} \mathrm{He}$} \\
\hline & & & Methane & Heavy hydrocarbon & $\mathrm{N}_{2}$ & $\mathrm{CO}_{2}$ & & & \\
\hline Fs6 & $\mathrm{K}_{1} \mathrm{yc}^{1}$ & 3413 & 78.93 & 2.03 & & 13.77 & -8.55 & 2.39 & \\
\hline Fs7 & $\mathrm{K}_{1} \mathrm{yc}^{1}$ & 3476 & 52.13 & 1.68 & 0.94 & 32.48 & -11.51 & 1.84 & \\
\hline Fs7 & $\mathrm{K}_{1} \mathrm{yc}^{1}$ & 3489 & 66.75 & 1.97 & 1.12 & 29.16 & -10.07 & 1.92 & \\
\hline Fs701 & $\mathrm{K}_{1} \mathrm{yc}^{1}$ & 3580 & 10.60 & 3.14 & 0.82 & 80.43 & -2.27 & 3.66 & \\
\hline Fs9 & $\mathrm{K}_{1} \mathrm{yc}^{1}$ & 3625 & 13.82 & 0.23 & 0.46 & 84.2 & -5.73 & 3.68 & $1.97 \times 10^{9}$ \\
\hline Fs9-1 & $\mathrm{K}_{1} \mathrm{yc}^{1}$ & 3650 & 11.13 & 2.67 & 0.98 & 87.25 & -3.49 & 2.71 & $1.96 \times 10^{9}$ \\
\hline
\end{tabular}


less likely to be formed by Mesozoic magma degassing. Thus, we conclude that once formed, the Mesozoic volcanic rocks served only as reservoirs, and the $\mathrm{CO}_{2}$ was derived from Cenozoic mantle-derived magmatic activity. Liu et al. (2016) identified a huge Cenozoic heat flow diapir approximately $40 \mathrm{~km}$ eastward from East Changde gas reservoirs by analyzing the seismic data acquired over Xujiaweizi Depression. Liu et al. (2016) further concluded that the heat flow diaper has a high impact on the $\mathrm{CO}_{2}$ gas in Changling, Wanjinta and Changde gas reservoirs. The work of Yu (Guo et al. 2017a, b) also shows that Cenozoic magmas are mainly basaltic, and the heat flow diapirs formed by this mantle-derived basaltic magmatic activity during the Himalayan structural evolution contained a large amount of volatiles, such as $\mathrm{CO}_{2}$, which then migrated along the major faults to the Mesozoic volcanic reservoirs where it accumulated. This is the current model for the formation of high $\mathrm{CO}_{2}$-content reservoirs in East Changde.

\subsection{Distribution of reservoirs and faults}

The distribution of faults and potential reservoirs significantly influences the distribution of $\mathrm{CO}_{2}$ reservoirs. Reservoir continuity is a key factor in studying the distribution of $\mathrm{CO}_{2}$ concentrations. Whether or not the seemingly horizontally interconnecting reservoirs are truly spatially connected largely determines the horizontal distribution of the $\mathrm{CO}_{2}$ concentration. However, basement faults serve as one of the key channels for the migration and accumulation of $\mathrm{CO}_{2}$. Therefore, close attention should be paid to faults, which can connect the various reservoirs, and heat flow diapirs, which can serve as gas sources.

\subsubsection{Reservoir distribution in the East Changde Gas Field}

In previous studies, the reservoirs intersected by wells Fs9, Fs9-1, Fs701, Fs7, and Fs6 were called the East Changde Gas Reservoir (Huo et al. 1998) and were treated as a uniform reservoir system. Thus, the $\mathrm{CO}_{2}$ contents of the various parts of one reservoir system should be approximately the same. However, the $\mathrm{CO}_{2}$ contents of Wells Fs6 and Fs7 in the East Changde Reservoir are both $<40 \%$, while the $\mathrm{CO}_{2}$ contents of wells Fs701 and Fs9, which are only $2.5 \mathrm{~km}$ away from wells Fs6 and Fs7, are $>80 \%$ (Fig. 4). This phenomenon sharply contradicts previous research findings.

In this study, comprehensive analysis of seismic, lithofacies, temperature, pressure (Guo et al. 2017a, b; Rui et al. 2017a, b; Wang et al. 2018), and $\mathrm{CO}_{2}$ content data suggests that there should be at least two sets of volcanic reservoirs, i.e., Fs6 and Fs7 are in one reservoir body, and Fs701, Fs91 , and Fs9 are in the other. The GR inversion data, collected by CNPC (Fig. 7), indicates that the volcanic reservoirs in East Changde are mainly distributed within the Lower Yingcheng Formation $\left(\mathrm{K}_{1} \mathrm{yc}^{1}\right)$. A thin volcanic reservoir is located in the northwestern region of Changde, and it is intersected by wells Fs6 and Fs7. The other reservoir is located in the central-southeastern part of the Xujiaweizi Depression. It is a 50-80-m-thick, large-scale reservoir, and it is intersected by wells Fs701, Fs9-1, and Fs9. These two sets of reservoirs are not interconnected.

In addition, the temperature and pressure data as well as the $\mathrm{CO}_{2}$ contents also indirectly verify the conclusions discussed above. As shown in Fig. 6, the temperatures and pressures of the stratum intersected by wells Fs9, Fs9-1, and Fs701 show a consistent positive correlation, suggesting that they share the same temperature-pressure system, whereas wells Fs6 and Fs7 are part of another temperature-pressure system that is not interconnected with the former. In terms of $\mathrm{CO}_{2}$ content, the five wells exhibit significant differences. The $\mathrm{CO}_{2}$ contents of wells Fs9, Fs9-1, and Fs701 are $>80 \%$, whereas those of wells Fs7 and Fs6 are $<40 \%$, i.e., $39.9 \%$ and $15.3 \%$, respectively. Figure 4 and Table 1 together indicate that the amount of $\mathrm{CO}_{2}$ within the pore space decreases with the increasing buried depth of our reservoir. Note that there exists a different declined trend of $\mathrm{CO}_{2}$ between Fs6-Fs7 and Fs701-Fs9-Fs901. This phenomenon indicates that there are two separate reservoirs.

\subsubsection{Fault distribution within the East Changde Gas Field}

The depth of the Moho in the Songliao Basin ranges from 29 to $34 \mathrm{~km}$. The higher $\mathrm{CO}_{2}$-content wells are mainly located in areas where the Moho depth is relatively shallow (less than $32 \mathrm{~km}$; Fig. 8), which indicates a strong connection between the $\mathrm{CO}_{2}$ and the mantle. As indicated by Fig. 8, the migration of $\mathrm{CO}_{2}$ is closely associated with the major basement faults, i.e., the high $\mathrm{CO}_{2}$-content wells are primarily located near basement faults, especially at the intersections of fault zones. Combining with the work of Zhang (Zhang 2003), it is concluded that basement faults are important channels that control the upwelling of $\mathrm{CO}_{2}$. The NS trend of the $\mathrm{CO}_{2}$ distribution (Fig. 8) in the Songliao Basin is mainly controlled by the Sunwu-Shuangliao lithospheric fault zone in the middle of the basin. Upper mantle upwelling resulted in a shallow Moho depth in this area and the formation of major deep faults, which resulted in the production of mantle-derived magma, i.e., the major source of the $\mathrm{CO}_{2}$ that was infused into the lithosphere.

The fault distribution in East Changde was investigated by means of a seismic section of the Xujiaweizi Depression. This investigation revealed the migration channels responsible for $\mathrm{CO}_{2}$ accumulation. We conclude that a large heat flow diapir developed near wells Xushen 23 and Xushen 21 (Figs. 1, 9b), and the seismic section exhibits 


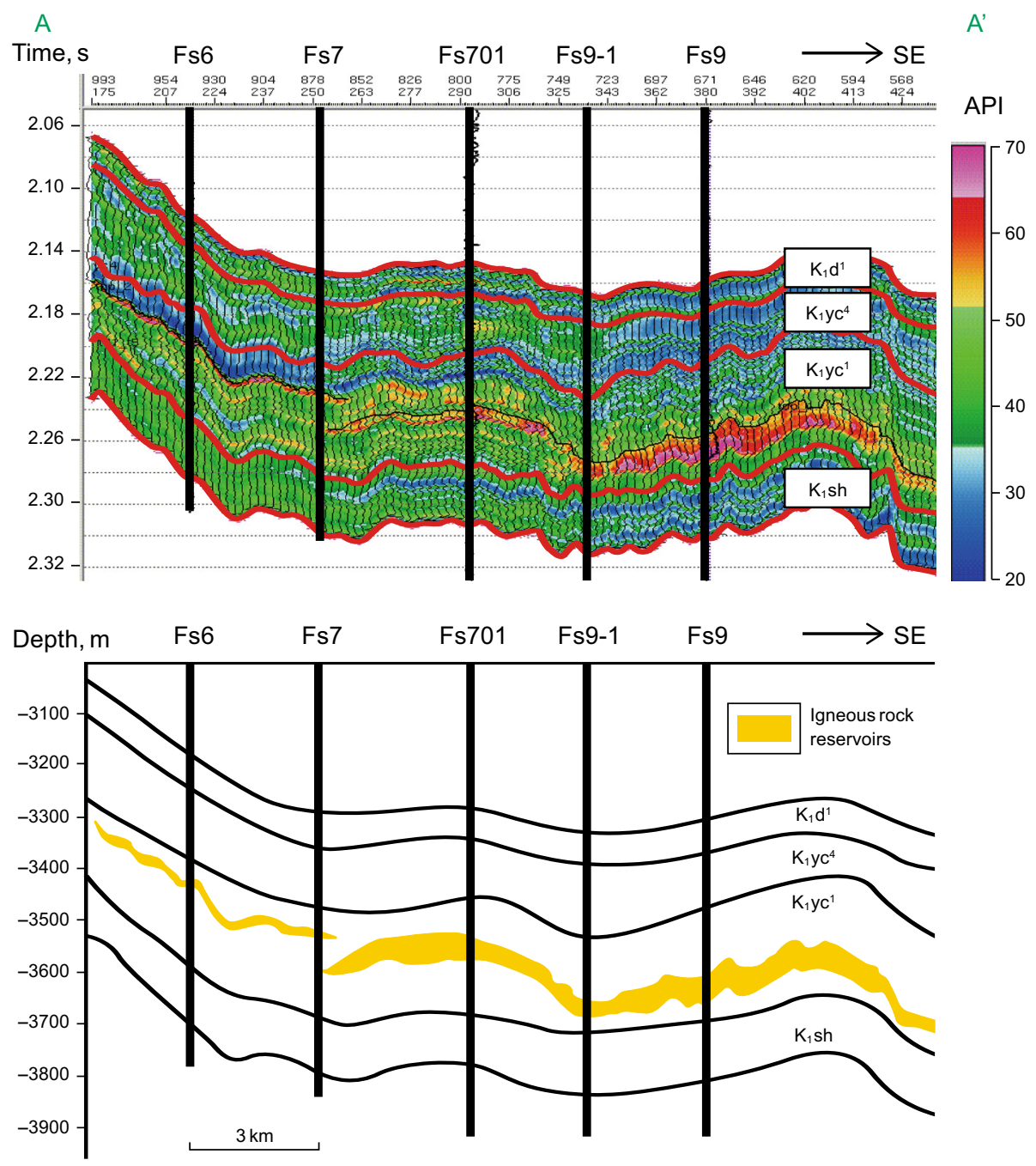

Fig. 7 Inverted seismic section of the reservoirs in East Changde

extremely chaotic reflection characteristics. This is highly consistent with that of the research conducted by CNPC (Figs. 1, 9a) (Liu et al. 2016). Supplied by mantle-sourced heat flow, this heat flow diapir migrated into the top of the Lower Cretaceous Huoshiling Formation and became an important $\mathrm{CO}_{2}$ source for the Xujiaweizi area. There are three basement faults in the Xujiaweizi Depression, i.e., the West Xu Fault, the Mid Xu Fault, and the East Xu Fault. These faults connect the heat flow diapir, which was generated by magmatic activity, with the Cretaceous volcanic reservoirs. With its small dip angle and large length, the West Xu Fault controls the formation of $\mathrm{CO}_{2}$ reservoirs in East Changde. It is worth noting that the West Xu Fault cuts the volcanic reservoir body in which wells Fs6 and Fs7 are located; however, it does not cut the reservoir body in which wells Fs701 and Fs9 are located.

\subsection{Migration and accumulation model}

The major basement faults and paleo-volcanic conduits that developed during the depositional stage of the Yingcheng Formation serve as channels for the upward migration of mantle-derived inorganic gases. These basement faults also serve as effective channels for organic hydrocarbons. As a result, both the major basement faults and the paleo-volcanic conduits are the major factors that control the migration, accumulation, and amount of organic hydrocarbon gases and mantle-derived inorganic gases in the volcanic rock reservoirs. In East Changde, the $\mathrm{CO}_{2}$ content is $>84 \%$ in the reservoir where wells Fs9 and Fs701 are located, but it is as low as $15 \%-40 \%$ in the reservoir where wells Fs7 and Fs6 are located. The distance between these reservoirs is less than $3 \mathrm{~km}$. In addition, Figs. 1 and 9 show that the heat flow diapir is located $40 \mathrm{~km}$ away to the east of the two reservoirs, and the migration of $\mathrm{CO}_{2}$ gas is mainly through basement faults and volcanic conduits. 


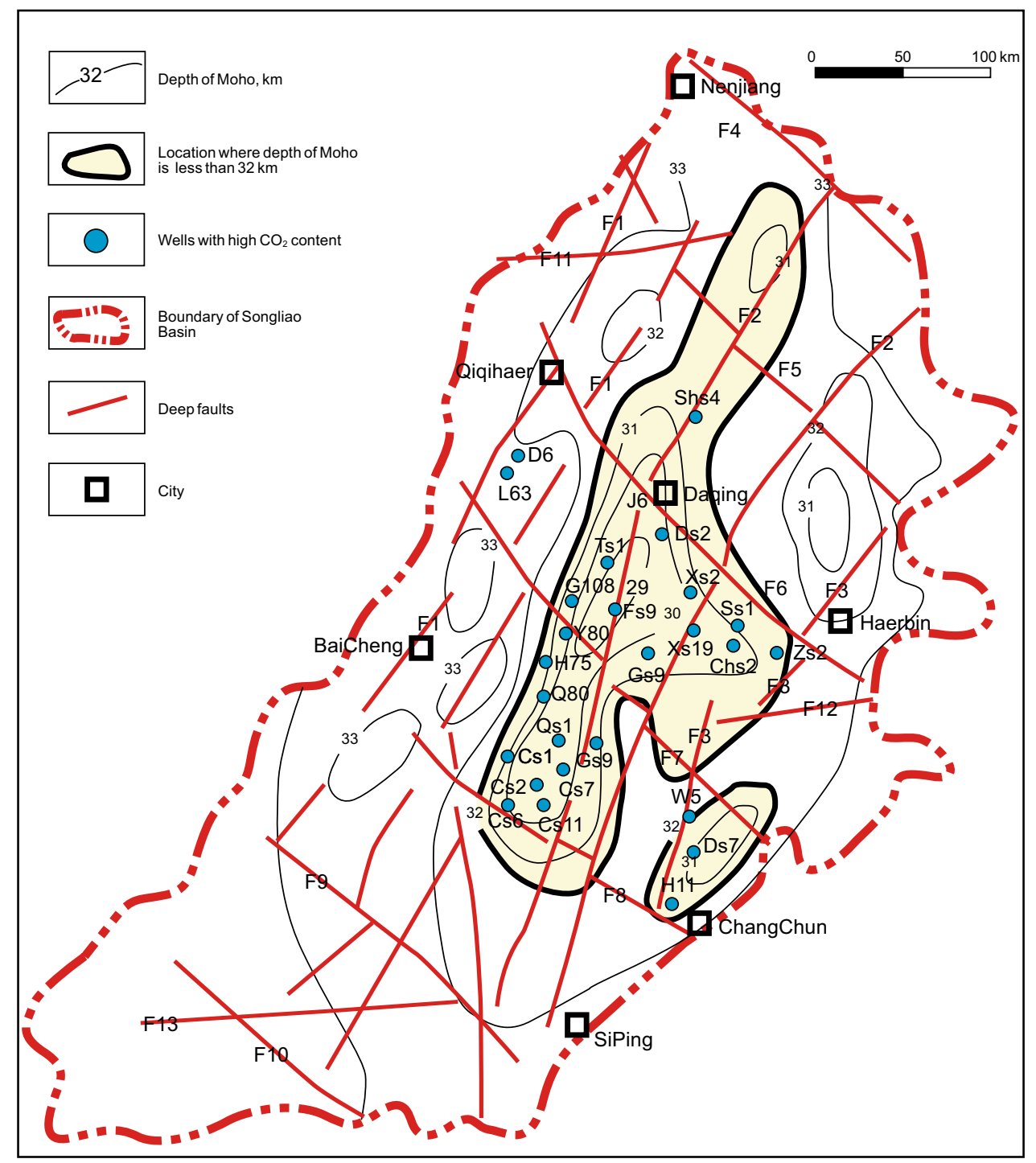

Fig. 8 Locations of the high $\mathrm{CO}_{2}$-content wells, the Moho depth, and the basement faults in the Songliao Basin. Note: F1, Nengjiang Fault Belt; F2, Sunwu-Shuangliao Fault Belt; F3, Harbin-Siping Fault Belt; F4, Jiagedaqi-Jixi Fault; F5, Nehe-Suihua Fault; F6, Binzhou

Thus, it is not very likely that the difference in the $\mathrm{CO}_{2}$ contents of the two reservoirs is directly caused by the location of the heat flow diapirs. The gas migration channels (faults and/or volcanic conduits) and related gas accumulation modes of the two reservoirs are the factors that control the large differences in the $\mathrm{CO}_{2}$ content of these reservoirs. In summary, there are two models for $\mathrm{CO}_{2}$ accumulation, i.e., the fault-controlled accumulation model and the volcanic conduit-controlled accumulation model (Fig. 10).

An example of the fault-controlled accumulation model is the volcanic body that is located above the West $\mathrm{Xu}$ Basement Fault and which is drilled by wells Fs6 and Fs7 (Fig. 10a). Many detailed studies (Liu et al. 2016) have
Fault; F7, Zhalaite-Jilin Fault; F8, Horqin-Yitong Fault; F9, TuquanSiping Fault; F10, Zhalute-Kaiyuan Fault; F11, Nemoerhe Fault; F12, Halamutu Fault; and F13, Xilamulun Fault

proven that the volcanic body in the Yingcheng Formation was formed at 117-102 Ma, i.e., Early Cretaceous, including the reservoir body intersected by wells Fs9, Fs91, Fs701, Fs7, and Fs6, before the Cenozoic $\mathrm{CO}_{2}$ emission. The West $\mathrm{Xu}$ basement fault extends upward along the volcanic conduit, cuts through the volcanic body, and extends upward into the Denglouku Formation. Studies conducted by the CNPC (Liu et al. 2016) in the Songliao Basin indicate that the West Xu Fault was formed in the Carboniferous-Permian, and it was active during the Mesozoic and Cenozoic. In addition, the study conducted by Lu SF (Lu et al. 2017) on the Shahezi Formation shows that the source rocks reached the gas generating stage at 100-80 Ma, when the West Xu Fault was highly active. So 

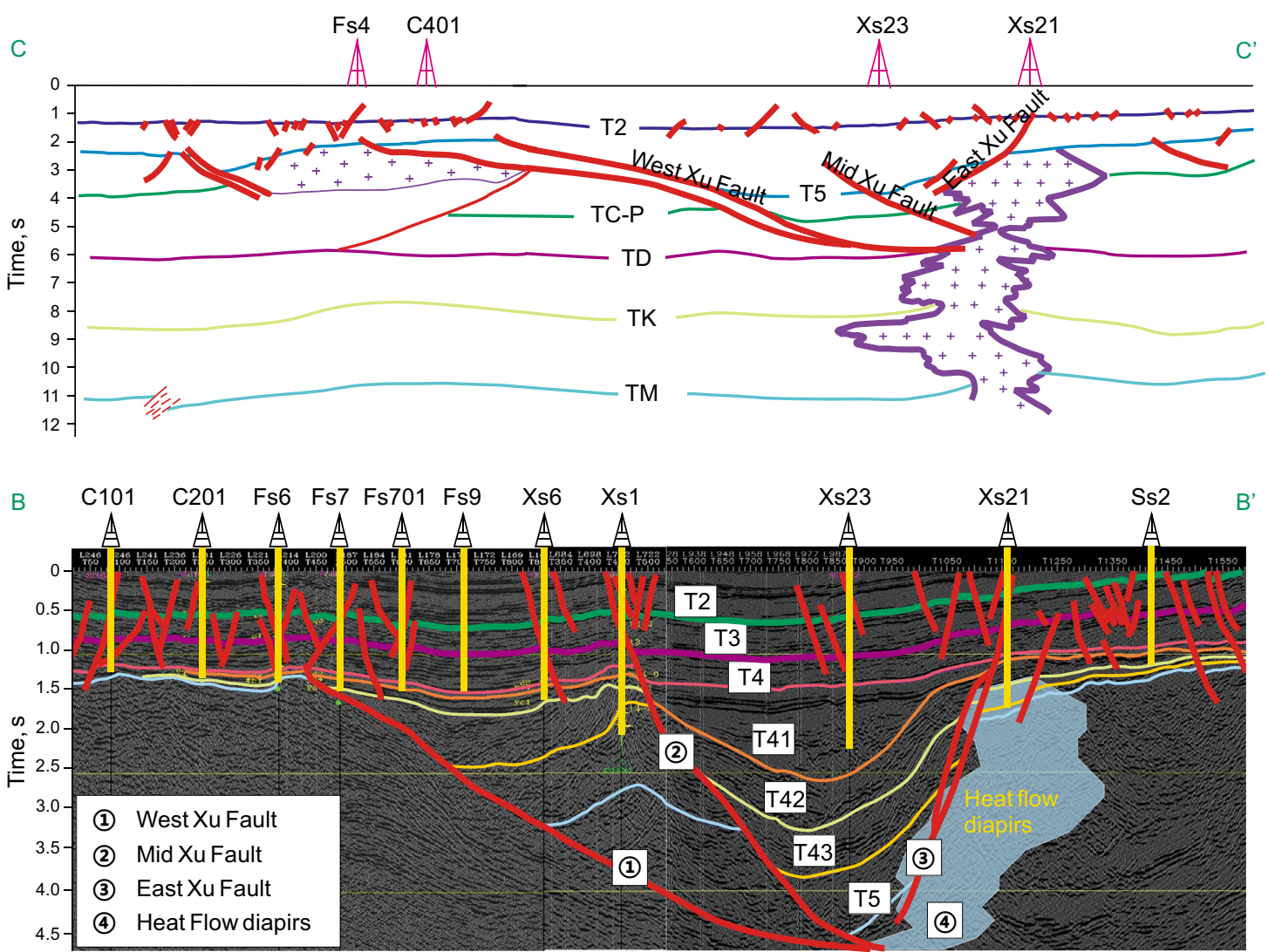

Fig. 9 Heat flow diapirs in Xujiaweizi, a interpretation of the seismic section (15 s) conducted by CNPC; $\mathbf{b}$ interpretation of the seismic section across Xujiaweizi). Note: T2, top of the Quantou Formation; T3, top of the Denglouku Formation; T4, top of member 4 of the Yingcheng Formation; T41, top of member 1 of the Yingcheng

a combination of these two conclusions shows that the West $\mathrm{Xu}$ Fault was open and active, allowing it to serve as a channel for the migration of the hydrocarbon gas into the volcanic reservoir. By connecting the heat flow diapir body located in the basement rocks, the volcanic conduits, the Lower Cretaceous Shahezi Formation, and the reservoirs, the West $\mathrm{Xu}$ Fault allowed mantle-derived $\mathrm{CO}_{2}$ to migrate and accumulate in the gas reservoir located along the West $\mathrm{Xu}$ Fault, and in the meantime hydrocarbon gases released from hydrocarbon-derived rocks in the strata of the Shahezi Formation also migrated and accumulated in this gas reservoir (Rui et al. 2017c, d; Cui et al. 2018a, b). This accounts for the coexistence of $\mathrm{CO}_{2}$ and hydrocarbon gases in wells Fs6 and Fs7, which resulted in a $\mathrm{CO}_{2}$ content lower than $40 \%$.

An example of the volcanic conduit-controlled accumulation model is the volcanic rock reservoir intersected by wells Fs701, Fs9-1, and Fs9 (Fig. 10b). This volcanic body was formed by intermediate magma that welled up along another volcanic conduit in the eastern part of the Xujiaweizi area. Lu et al. (2009) studied the structural evolution and characteristics in Xujiaweizi area and
Formation; T42, top of the Shahezi Formation; T43, top of the Huoshiling Formation; T5, top of the basement; TC-P, top of the Carboniferous-Permian Formation; TD, detachment surface; TK, Conrad discontinuity; TM, Moho surface; the location of $\mathrm{CC}^{\prime}$ and $\mathrm{BB}^{\prime}$ is referred to Fig. 1

concluded that neither the volcanic conduit nor the reservoir body was damaged by later structural events. As a result, mantle-derived $\mathrm{CO}_{2}$ was able to migrate from the heat flow diapir upward along the volcanic conduit and accumulate in the volcanic reservoir. Without a fault to provide a migration path, hydrocarbon gases in the strata of the underlying Shahezi Formation could not accumulate in the reservoir body (Sun et al. 2016; Wang et al. 2017), which resulted in $\mathrm{CO}_{2}$ contents as high as 70\%-80\% in wells Fs701, Fs9-1, and Fs9.

The two accumulation models mentioned above seem to provide foundations for predicting $\mathrm{CO}_{2}$ content in East Changde. As mentioned above, the horizontal distribution of $\mathrm{CO}_{2}$ content is highly heterogeneous, and we concluded that this heterogeneity could be explained by the accumulation pathways. If the igneous rock reservoirs are cut by basement faults, then the $\mathrm{CO}_{2}$ content would be generally less than $40 \%$ because the mixture of hydrocarbon gases. The low $\mathrm{CO}_{2}$ content in the reservoir at the borehole places of Well Fs6 and Fs7 indicate that the basement faults in East Changde are open as the avenue for hydrocarbon migration. If the igneous rock reservoirs connect 


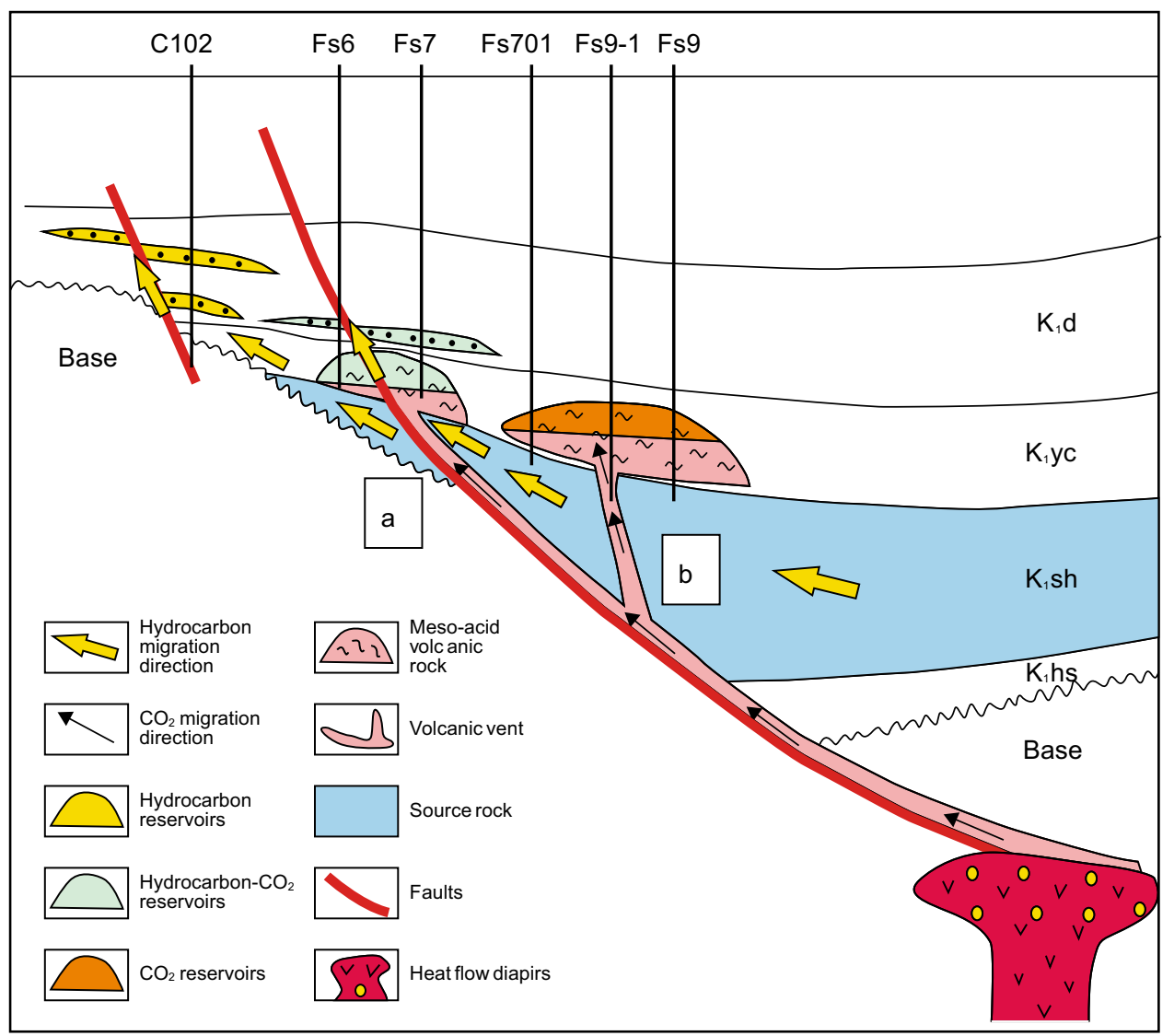

Fig. 10 Accumulation models for $\mathrm{CO}_{2}$-containing reservoirs in East Changde, a fault-controlled accumulation model; b volcanic conduitcontrolled accumulation model)

with a volcanic conduit instead of being cut by basement faults, then the $\mathrm{CO}_{2}$ content would be generally greater than $70 \%$.

\section{Conclusions}

In this study, the following conclusions have been reached:

1. The $\mathrm{CO}_{2}$ reservoirs in East Changde are actually two sets of disconnected silicic volcanic reservoirs located in the Yingcheng Formation $\left(\mathrm{K}_{1} \mathrm{yc}^{1}\right)$. One set of reservoirs is intersected by wells Fs6 and Fs7, and the other set is intersected by wells Fs701 and Fs9. The gas migration channels (faults or volcanic conduits) and gas accumulation modes of the two well areas (sets of reservoirs) are the factors that control the large differences in the $\mathrm{CO}_{2}$ content of these reservoirs.

2. The $\mathrm{CO}_{2}$ migration and accumulation in East Changde can be accounted for by two models, i.e., a faultcontrolled accumulation model and a volcanic conduitcontrolled accumulation model. The reservoirs formed by these models vary significantly. In the faultcontrolled gas supply model, hydrocarbon gases in the underlying strata migrate and accumulate in the reservoir, which results in lower $\mathrm{CO}_{2}$-content reservoirs. Whereas in the volcanic conduit-controlled accumulation model, $\mathrm{CO}_{2}$ migrates directly from the heat flow diapir to the reservoirs, and the hydrocarbon gases cannot effectively enter, resulting in higher $\mathrm{CO}_{2}-$ content reservoirs.

Acknowledgements This research was founded by the S\&T development project "Key Factors Controlling Accumulation in Old Petroleum System (No. 2016A-0206)" by the China National Petroleum Corporation.

Open Access This article is distributed under the terms of the Creative Commons Attribution 4.0 International License (http://creative commons.org/licenses/by/4.0/), which permits unrestricted use, distribution, and reproduction in any medium, provided you give appropriate credit to the original author(s) and the source, provide a link to the Creative Commons license, and indicate if changes were made.

\section{References}

Ballentine CJ, Schoell M, Coleman D, et al. Magmatic $\mathrm{CO}_{2}$ in natural gases in the Permian Basin, West Texas: identifying the regional 
source and filling history. $\mathrm{J}$ Geochem Explor. 2000;70:59-63. https://doi.org/10.1016/S0375-6742(00)000455.

Cao RL. Frontiers of research on the mantle fluids. Earth Sci Front. 1996;3(4):161-71.

Cui G, Ren S, Rui ZH, et al. The influence of complicated fluid-rock interactions on the geothermal exploitation in the $\mathrm{CO}_{2}$ plume geothermal system. Appl Energy. 2018a. https://doi.org/10.1016/ j.apenergy.2017.10.114.

Cui G, Wang Y, et al. Assessing the combined influence of fluid-rock interactions on reservoir properties and injectivity during $\mathrm{CO}_{2}$ storage in saline aquifers. Energy. 2018b;155:281-96. https:// doi.org/10.1016/j.energy.2018.05.024.

Dai JX. Geochemistry and accumulation of carbon dioxide gases in China. AAPG Bull. 1996;80(10):1615-26.

Du LT. Progress in the study of inorganic genetic $\mathrm{CO}_{2}$ gas reservoirs. Pet Geol Oilfield Dev Daqing. 2005;24(2):1-4 (in Chinese).

$\mathrm{Fu} \mathrm{XF}$, Song Y. Inorganic gas and its resources in Songliao Basin. Acta Pet Sin. 2005;26(4):23-8 (in Chinese).

Guan XR. Genesis of carbon dioxide of high purity in east China. Exp Pet Geol. 1990;12(3):248-58 (in Chinese).

Guo ZQ, Wang XB, Yang BZ, et al. Abiogenic gas reservoir modes found in Songliao Basin. Nat Gas Ind. 2000;20(6):30-3 (in Chinese)

Guo J, Luo B, et al. Numerical investigation of hydraulic fracture propagation in a layered reservoir using the cohesive zone method. Eng Fract Mech. 2017a;186:195-207. https://doi.org/ 10.1016/j.engfracmech.2017.10.013.

Guo TK, Li YC, Ding Y, et al. Evaluation of acid fracturing treatments in shale formation. Energy Fuel. 2017b;31(10):10479-89. https://doi.org/10.1021/acs.energy fuels.7b01398.

He JX, Xia B, Liu BM, et al. Origin, migration and accumulation of $\mathrm{CO}_{2}$ in East China and offshore shelf basins. Pet Explor Exploit. 2005;32(4):42-9.

Huo QL, Yang BZ, Fu L. Genesis of natural gas of eastern Changde gas pool in northern Songliao Basin. Pet Explor Dev. 1998;25(4):9-17.

Li JK, Feng ZH, Liu W, et al. Research on reservoir forming time of deep natural gas in Xujiaweizi faulted depression in Songliao Basin. Acta Pet Sin. 2006;27:42-6 (in Chinese).

Lin JY, Jiang T, Song LB, et al. The origin and gas vertical distribution of the Harjin mixed-gas reservoir. Acta Pet Sin. 2010;31(6):927-32 (in Chinese).

Liu DL, Li ZS, Liu B, et al. Potential to form $\mathrm{CO}_{2}$ reservoirs through adsorption of $\mathrm{CO}_{2}$ by volcanic rocks and case study. Reg Geol China. 2005;24(10-11):962-7 (in Chinese).

Liu SB, Lu XS, Hong F, et al. Accumulation mechanisms and distribution patterns of $\mathrm{CO}_{2}$-containing natural gas reservoirs in the Songliao Basin. Beijing: Science Press; 2016. p. 67-73 (in Chinese).

Lu XS, Song Y, Liu SB, et al. Progress in the studies of mantlederived $\mathrm{CO}_{2}$ degassing mechanism, degassing model and poolforming mechanism. Earth Sci Front. 2008;15(6):293-302 (in Chinese)

Lu XS, Song Y, Liu SB, et al. Distribution and migration-accumulation mechanism of mantle-derived $\mathrm{CO}_{2}$ in Songliao Basin. Acta Pet Sin. 2009;30(5):661-6 (in Chinese).

Lu SF, Gu MW, Zhang FF, et al. Hydrocarbon accumulation stages and type division of Shahezi Fm tight glutenite gas reservoirs in the Xujiaweizi Rift basin, Songliao Basin. Nat Gas Ind. 2017;37(6):12-21 (in Chinese).

Marty B, Jambon A, Sano Y. Helium isotopes and $\mathrm{CO}_{2}$ in volcanic gases of Japan. Chem Geol. 1989;76(1-2):25-40. https://doi.org/ 10.1016/0009-2541(89)90125-3.
Mysen BO, Arcyllus RJ, Eggler DH. Solubility of carbon dioxide in melts of andesite, tholeiite, and olivine nephelinite composition to $30 \mathrm{kbar}$ pressure. Contrib Miner Pet. 1975;53(4):227-39. https://doi.org/10.1007/BF00382441.

$\mathrm{Qu}$ X, Chen X, Yu M, et al. Mineral dating of mantle-derived $\mathrm{CO}_{2}$ charging and its application in the southern Songliao Basin, China. Appl Geochem. 2016;68:19-28. https://doi.org/10.1016/j. apgeochem.2016.03.005.

Rui ZH, Lu J, Zhang ZE, et al. A quantitative oil and gas reservoir evaluation system for development. J Nat Gas Sci Eng. 2017a;4:31-9. https://doi.org/10.1016/j.jngse.2017.02.026.

Rui ZH, Han G, Zhang H, et al. A new model to evaluate two leak points in a gas pipeline. $J$ Nat Gas Sci Eng. 2017b;46:491-7. https://doi.org/10.1016/j.jngse.2017.08.025

Rui ZH, Li CC, Peng F, et al. Development of industry performance metrics for offshore oil and gas project. J Nat Gas Sci Eng. 2017c;39:44-53. https://doi.org/10.1016/j.jngse.2017.01.022.

Rui ZH, Peng F, Ling KG, et al. Investigation into the performance of oil and gas projects. J Nat Gas Sci Eng. 2017d;38:12-20. https:// doi.org/10.1016/j.jngse.2016.11.049.

Rui ZH, Wang X, et al. A realistic and integrated model for evaluating oil sands development with steam assisted gravity drainage technology in Canada. Appl Energy. 2018a;213:76-91. https://doi.org/10.1016/j.apenergy.2018.01. 015.

Rui ZH, Cui K, et al. A comprehensive investigation on performance of oil and gas development in Nigeria: technical and nontechnical analyses. Energy. 2018b;158:666-80. https://doi.org/ 10.1016/j.energy.2018.06.027.

Sano Y, Wakita H, Huang C. Helium flux in a continental land area estimated from ${ }^{3} \mathrm{He} /{ }^{4} \mathrm{He}$ ratio in northern Taiwan. Nature. 1986;323(6083):55-7. https://doi.org/10.1038/323055a0.

Shao ML, Men JH, Wei ZP. The genesis type and enrichment condition of the $\mathrm{CO} 2$ in the southern part of Songliao Basin. Pet Geol Oilfield Dev Daqing. 2000;19(4):1-3 (in Chinese).

Sun FJ, Jiao GH, Luo X, et al. The origin and formation of $\mathrm{CO}_{2}$ gas pools in Songliao Basin, China. $\mathrm{J}$ Geochem Explor. 2009;101(1):99. https://doi.org/10.1016/j.gexplo.2008.12.054.

Sun J, Gamboa E, Schechter D, et al. An integrated workflow for characterization and simulation of complex fracture networks utilizing microseismic and horizontal core data. J Nat Gas Sci Eng. 2016;34:1347-1360. https://doi.org/10.1016/j.jngse.2016. 08.024 .

Tan Y, Zhang CM, Liu DL. Geochemical criterion of $\mathrm{CO}_{2}$ origin of Changdedong gas deposit in north of Songliao Basin. Offshore oil. 2005;25(3):18-23 (in Chinese)

Trull T, Nadeau S, Pineau F, et al. C-He systematics in hotspot xenoliths: implications for mantle carbon contents and carbon recycling. Earth Planet Sci Lett. 1993;118(1-4):43-64. https:// doi.org/10.1016/0012-821X(93)90158-6.

Wang L, Wang SH, Zhang RL, et al. Review of multi-scale and multiphysical simulation technologies for shale and tight gas reservoir. J Nat Gas Sci Eng. 2017;37:560-78. https://doi.org/10. 1016/j.jngse.2016.11.051.

Wang XX, Hou JG, Song SH, et al. Combining pressure-controlled porosimetry and rate-controlled porosimetry to investigate the fractal characteristics of full-range pores in tight oil reservoirs. J Petrol Sci Eng. 2018;171:353-61. https://doi.org/10.1016/j. petrol.2018.07.050.

Wei LC, Lu XS, Song Y, et al. Formation and pool-forming model of $\mathrm{CO}_{2}$ gas pool in eastern Changde area, Songliao Basin. Petrol Explor Dev. 2009;36(2):174-80.

Xu S, Nakai S, Wakita $\mathrm{H}$, et al. Mantle-derived noble gases in natural gases from Songliao Basin, China. Geochim Et Cosmochim Ac. 1995;59(22):4675-83. 
$\mathrm{Xu}$ D, Zhou YQ, Zhu YL, et al. $\mathrm{CO}_{2} /^{3} \mathrm{He}$ ratio of mantle derived $\mathrm{CO}_{2}$ gas pools and its formation mechanism in east China. Oil Gas Geol. 1999;20(4):290-4 (in Chinese).

Yang G, Zhao ZY, Shao ML. Formation of carbon dioxide and hydrocarbon gas reservoirs in the Changling Rift basin, Songliao Basin. Pet Explor Dev. 2011;38(1):52-8.

Yu D, Lv YF, Fu XF, et al. Characteristics of fault structure and its control on deep gas reservoir in Xujiaweizi Rift basin, Songliao Basin. Geol Rev. 2010;56(2):237-45 (in Chinese).

Zeng J, Wang X, et al. Composite linear flow model for multifractured horizontal wells in heterogeneous shale reservoir. J Nat
Gas Sci Eng. 2017;38:527-48. https://doi.org/10.1016/j.jngse. 2017.01.005.

Zhang XD. Analysis on genesis and accumulation law of carbon dioxide gas reservoirs in the northeastern areas of China. Acta Geol Sin. 2003;24(6):13-23 (in Chinese).

Zhang JH, Feng W, Li J, et al. Deep gases and their genetic types of the Xujiaweizi Rift basin zone, Songliao Basin and their contribution. Acta Geol Sin. 2009;83(4):579-89 (in Chinese). 